\title{
Effect of Vermicompost and Biofertilizers on Yield Attributes and Nutrient Content and it's their Uptake of Cowpea [Vigna unguiculata (L.)Walp.]
}

\author{
V.M. Khan ${ }^{1 *}$, Atik Ahamad ${ }^{2}$, B.L. Yadav ${ }^{1}$ and Mohammad Irfan ${ }^{1}$ \\ ${ }^{1}$ Department of Soil Science and Agricultural Chemistry, S.K.N. College of Agriculture, \\ Jobner -303329, Sri Karan Narendra Agriculture University, Jobner, Jaipur (Rajasthan), India \\ ${ }^{2}$ Department of Soil Science and Agricultural Chemistry, NDUA\&T, Kumarganj-224229 \\ Faizabad (U.P.), India \\ *Corresponding author
}

\begin{tabular}{|c|c|}
\hline & A B S T R A C T \\
\hline & \multirow{8}{*}{$\begin{array}{l}\text { A field experiment was conducted at Agronomy Farm, S.K.N. College of } \\
\text { Agriculture, Jobner (Jaipur) during kharif season 2012. The results revealed } \\
\text { that application of vermicompost @ } 6.0 \text { t/ha gave significantly higher yield } \\
\text { attributing characters (Number of pods per plant and Number of seeds per } \\
\text { pod) and further application of Rhizobium }+ \text { PSB recorded significantly } \\
\text { higher yield attributing characters (Number of pods per plant and Number } \\
\text { of seeds per pod) over control, but both are treatments did not significantly } \\
\text { effect of test weight. The results revealed that increase in nitrogen content } \\
\text { and uptake in seed and straw with } 6.0 \text { t/ha vermicompost recoded } \\
\text { statistically at par with } 4.0 \text { t/ha vermicompost treatment and further } \\
\text { application of Rhizobium }+ \text { PSB observed significantly NPK content and } \\
\text { their uptake by seed and straw over control. }\end{array}$} \\
\hline Keywords & \\
\hline & \\
\hline $\begin{array}{l}\text { Biofertilizers, } \\
\text { Seed, Straw, }\end{array}$ & \\
\hline Content and Uptake. & \\
\hline Article Info & \\
\hline $\begin{array}{l}\text { Accepted: } \\
\text { 17 May } 2017 \\
\text { Available Online: } \\
\text { 10 June } 2017\end{array}$ & \\
\hline & \\
\hline
\end{tabular}

\section{Introduction}

Cowpea [Vigna unguiculata (L.) Walp] commonly known in India as labia is one of the important kharif pulse crops grown for vegetable, grain, forage and green manuring. Pulse crops leave behind reasonable quantity of nitrogen in soil to the extent of $30 \mathrm{~kg} / \mathrm{ha}$. In India pulses are grown nearly in $25.43 \mathrm{~m}$ ha with an annual production of $17.28 \mathrm{~m} \mathrm{t}$ and an average productivity of $679 \mathrm{~kg} / \mathrm{ha}$ (Anonymous, 2012). In Rajasthan the area under pulses is 47.54 lakh ha with an annual production of 32.54 lakh $\mathrm{m} \mathrm{t}$ and an average productivity of $684 \mathrm{~kg} / \mathrm{ha}$ and the area under Cowpea is 1.02 lakh ha with the production of 0.64 lakh tonnes and productivity of 529 $\mathrm{kg} / \mathrm{ha}$ (Anonymous, 2011). The per capita availability of pulses in India is $35.5 \mathrm{~g} /$ day as against the minimum requirement of 70 g/day/capita as advocated by Indian Council of Medical Research (Anonymous, 2009).

The dose of fertilizer depends on the initial soil fertility status and moisture availability conditions. Although cowpea is a legume and 
capable of fixing atmospheric nitrogen, still it responds to small quantity of nitrogenous fertilizers applied as starter dose. Application of $15-20 \mathrm{~kg} \mathrm{~N} / \mathrm{ha}$ has been found optimum to get better response. Application of higher dose of nitrogen may reduce nodule number and nodule growth and thus adversely affects the nitrogen fixation capacity (Singh and Nair, 1995). In terms of significance, phosphorus is most indispensable mineral nutrient for pulse crops as it helps in better root growth and development and thereby making them more efficient in biological nitrogen fixation.

Use of biofertilizers can have a greater importance in increasing fertilizer use efficiency. Indian soils are poor to medium status in available nitrogen and available phosphorus. The seed of pulses is inoculated with Rhizobium with an objective of increasing their number in the rhizosphere, so that there is substantial increase in the microbiologically fixed nitrogen for the plant growth. The inoculation of seeds with suitable Rhizobium culture increased the green pod yield over uninoculated control (Vaisya et al., 1983). The association of Rhizobium and pulse plants helps in improving fertility of soil and is a cost effective method of nitrogen fertilization in legumes.

\section{Materials and Methods}

A field experiment was conducted at Agronomy farm, S.K.N. College of Agriculture, Jobner (Jaipur) during kharif season 2012 to study the effect of vermicompost and biofertilizers on growth, yield and quality of cowpea (Vigna unguiculata (L.) Walp.) grown on irrigated loamy sand soil of semi-arid eastern plain zone of Rajasthan. The experiment consists of four levels of vermicompost (Control, 2.0, 4.0 and $6.0 \mathrm{t} / \mathrm{ha}$ ) and four levels of biofertilizers (Control, Rhizobium, PSB and Rhizobium +
PSB), thereby making sixteentreatment combinations were replication four times in Factorial Randomized Block design. The soil was loam sandy in texture with $\mathrm{pH} 8.20$, organic carbon $0.15 \%$. Available N,P,K, $135.0,16.25$ and $160.0 \mathrm{~kg} / \mathrm{ha}$ respectively. The soil moisture content at field capacity and permanent wilting point was 12.7 and $2.64 \%$, respectively, with bulk density $1.47 \mathrm{Mg} / \mathrm{m} 3$ of 0-15 cm layer.

The maximum temperature ranged from 37.2 to $17.90 \mathrm{C}$ during 2012 . The relative humidity ranged between 89 to 43 per cent. The average sunshine fluctuated between 09.4 to 0.6 hours/day. The total rainfall received during the crop season (2012) was $520.4 \mathrm{~mm}$. geographically, Jobner is situated $45 \mathrm{~km}$ west of Jaipur at 2605 " North latitude and 75028 " east longitudes at an altitude of 427 meters above mean sea level. In Rajasthan, this region falls under Agro-climatic zone-IIIA (Semi-Arid Eastern Plains).

\section{Results and Discussion}

\section{Yield attributes}

\section{Effect of vermicompost}

The data presented in (Table 1) indicate that with the application of vermicompost there was a significant increase in number of pods per plant and number of seeds per pod of cowpea under V2, V4 and V6 treatments as compared to control (V0). However, the increase in number of pods per plant with V6 treatment was statistically at par with V4 treatment.

The application of vermicompost under V2, $\mathrm{V} 4$ and V6 treatments increased the number of pods per plant to the extent of $24.46,35.16$, $37.30,15.58,23.58$ and 29.41 per cent, respectively, over control (V0).Since the vermicompost being a store house of almost 
all the plant nutrient required for proper growth and development of plants, its addition the in soil enhanced availability of these nutrients.

Thus the improvement in soil environment of encouraged proliferation of plant roots, which helped to draw more water and nutrients from larger area and deeper layers and thus owing to higher availability of nutrients, synthesis of more carbohydrates and their translocation to different plant parts resulted increased vegetative growth including the reproductive structures. These results corroborate with the finding of Sharma (2001).

\section{Effect of biofertilizers}

It is evident from the data in (Table-1) that due to inoculation of cowpea seed with Rhizobium, PSB and Rhizobium + PSB there was a significant increase in number of pods per plant and number of seeds per pod of cowpea in comparison to control. The increase in number of pods per plant with Rhizobium + PSB was also statistically significant over Rhizobium as well as PSB inoculations.

However, the increase in number of pods per plant and number of seeds per pod with inoculation of Rhizobium was statistically at par with that of PSB. The increase in number of pods per plant and number of seeds per pod of cowpea with Rhizobium, PSB and Rhizobium + PSB inoculations was to the extent of 9.33, 6.0, 18.0, 11.88, 11.32 and 23.37, per cent respectively, over control. Rhizobium + PSB might have improved both nitrogen and available phosphorus in rhizophere as they are symbiotic nitrogen fixers and phosphorus solubilizers, respectively.

Thus, the increased availability of nitrogen due to Rhizobium coupled with phosphors due to PSB might open the door for increased utilization of others nutrient also and have resulted in more increase in growth, yield attributes and ultimately the yield in comparison to Rhizobium and PSB inoculations similar finding also reported by Yadav (2001) in cowpea and Kumawat et al., (2010) in green gram.

A perusal of data (Table 1) indicates that test weight was not significantly affected by different levels of vermicompost as well as biofertilizers.

\section{Nutrient content and their uptake}

\section{Effect of vermicompost}

The data presented in the (Table 2) indicate that with the application vermicompost there was a significant increase in nitrogen content and uptake in seed and straw of cowpea under $\mathrm{V} 2$, V4 and V6 treatments as compared to control (V0). However, the increase in nitrogen content and uptake in seed and straw with V6 treatment was statistically at par with $\mathrm{V} 4$ treatment.

The application of vermicompost under $\mathrm{V} 2, \mathrm{~V} 4$ and V6 treatments increased the nitrogen content and uptake in seed to the extent of 8.18, 12.57, 15.20, 40.65,71.96 and 85.01 per cent and whereas, increase in straw was to the extent of $25.0,35.93,40.62$, $62.23,104.07$ and 120.70 per cent, respectively, over control (V0).

A perusal of data in table 2 indicate that with the application of vermicompost there was a significant increase in phosphorus content and uptake in seed and straw of cowpea under $\mathrm{V} 2, \mathrm{~V} 4$ and V6 treatments as compared to control (V0). However, the increase in phosphorus content and uptake in seed and straw with V6 treatment was statistically at par with V4 treatment. 
Table.1 Effect of vermicompost and biofertilizers on number of pods per plant, number of seeds per pod and test weight

\begin{tabular}{lccc}
\hline Treatment & $\begin{array}{c}\text { Number of pods per } \\
\text { plant }\end{array}$ & $\begin{array}{c}\text { Number of Seeds } \\
\text { per pod }\end{array}$ & Test weight (g) \\
\hline Vermicompost & & & \\
levels & & & \\
$\mathrm{V}_{0}$ & 6.54 & 6.80 & 74.80 \\
$\mathrm{~V}_{2}$ & 8.14 & 7.86 & 75.62 \\
$\mathrm{~V}_{4}$ & 8.84 & 8.41 & 76.20 \\
$\mathrm{~V}_{6}$ & 8.98 & 8.80 & 76.26 \\
SEm & 0.17 & 1.43 \\
CD $(0.05 \%)$ & 0.14 & 0.49 & $\mathrm{NS}$ \\
Biofertilizers & 0.39 & & 74.94 \\
Control & & 7.15 & 76.13 \\
Rhizobium & 7.50 & 8.00 & 75.61 \\
PSB & 8.20 & 7.96 & 76.20 \\
Rhizobium + PSB & 7.95 & 8.75 & 1.43 \\
SEm & 8.85 & 0.17 & $\mathrm{NS}$ \\
CD $(0.05 \%)$ & 0.14 & 0.49 & \\
\hline
\end{tabular}

Table.2 Effect of vermicompost and biofertilizers on NPK content and uptake in seed and straw

\begin{tabular}{lcccccccccccc}
\hline Treatments & \multicolumn{2}{c}{$\begin{array}{c}\text { N content } \\
(\boldsymbol{\%})\end{array}$} & \multicolumn{2}{c}{$\begin{array}{c}\text { N uptake } \\
(\mathbf{k g} / \mathbf{h a})\end{array}$} & \multicolumn{2}{c}{$\begin{array}{c}\text { P content } \\
(\boldsymbol{\%})\end{array}$} & \multicolumn{2}{c}{$\begin{array}{c}\text { P uptake } \\
(\mathbf{k g} / \mathbf{h a})\end{array}$} & \multicolumn{2}{c}{$\begin{array}{c}\text { K content } \\
(\boldsymbol{\%})\end{array}$} & \multicolumn{2}{c}{$\begin{array}{c}\text { K uptake } \\
(\mathbf{k g} / \mathbf{h a})\end{array}$} \\
\cline { 2 - 12 } & Seed & Straw & Seed & Straw & Seed & Straw & Seed & Straw & Seed & Straw & Seed & Straw \\
\hline Vermicompost levels & & & & & & & & & & & & \\
$\mathrm{V}_{0}$ & 3.42 & 1.28 & 30.50 & 20.38 & 0.324 & 0.184 & 2.90 & 2.95 & 1.18 & 1.46 & 10.57 & 23.25 \\
$\mathrm{~V}_{2}$ & 3.70 & 1.60 & 42.90 & 32.86 & 0.349 & 0.203 & 4.05 & 4.19 & 1.47 & 1.75 & 17.13 & 35.93 \\
$\mathrm{~V}_{4}$ & 3.85 & 1.74 & 52.45 & 41.59 & 0.369 & 0.218 & 5.04 & 5.21 & 1.68 & 1.96 & 23.03 & 46.84 \\
$\mathrm{~V}_{6}$ & 3.94 & 1.80 & 56.43 & 44.98 & 0.384 & 0.228 & 5.50 & 5.68 & 1.77 & 2.05 & 25.55 & 51.14 \\
SEm & 0.03 & 0.03 & 1.46 & 1.41 & 0.006 & 0.005 & 0.17 & 0.19 & 0.04 & 0.04 & 0.85 & 1.64 \\
CD (0.05\%) & 0.09 & 0.08 & 4.17 & 4.00 & 0.018 & 0.013 & 0.48 & 0.53 & 0.12 & 0.11 & 2.42 & 4.66 \\
Biofertilizers & & & & & & & & & & & & \\
Control & 3.45 & 1.42 & 36.57 & 26.90 & 0.333 & 0.181 & 3.55 & 3.41 & 1.33 & 1.64 & 14.36 & 30.99 \\
Rhizobium & 3.80 & 1.64 & 46.67 & 35.87 & 0.353 & 0.206 & 4.34 & 4.48 & 1.54 & 1.83 & 19.26 & 40.03 \\
PSB & 3.75 & 1.62 & 45.18 & 34.87 & 0.360 & 0.215 & 4.36 & 4.59 & 1.50 & 1.77 & 18.43 & 38.07 \\
Rhizobium $+\mathrm{PSB}$ & 3.91 & 1.74 & 53.86 & 42.17 & 0.379 & 0.231 & 5.24 & 5.55 & 1.73 & 1.98 & 24.25 & 48.07 \\
SEm & 0.03 & 0.03 & 1.46 & 1.41 & 0.006 & 0.005 & 0.17 & 0.19 & 0.04 & 0.04 & 0.85 & 1.64 \\
CD (0.05\%) & 0.09 & 0.08 & 4.17 & 4.00 & 0.018 & 0.013 & 0.48 & 0.53 & 0.12 & 0.11 & 2.42 & 4.66 \\
\hline
\end{tabular}

The application of vermicompost under V2,V4 and V6 treatments increased the phosphorus content and uptake in seed to the extent of $7.16,13.88,23.51,39.65,73.79$ and 89.65 per cent whereas, increase phosphorus content in straw was to the extent of 10.32 , $18.47,23.91,42.03,76.61$ and 92.54 per cent respectively, over control(V0).A perusal of data presented in table 2 revealed that with the application of vermicompost there was a significant increase in potassium content and uptake in seed and straw of cowpea under V2, V4and V6 treatments as compared to control(V0). However, the increase in potassium content and uptake in seed and straw with V6 treatment was statistically at par with V4 treatment. 
The application of vermicompost under V2, V4 and V6 treatments increased the potassium content and uptake in seed to the extent of 24.57, 42.37, 50.0, 15.78, 12.78 and 30.07 per cent whereas, increase in potassium content in straw was to the extent of 19.86 , $32.24,40.41,11.58,7.92$ and 20.73 per cent, respectively, over control (V0).Data in table 2 showed that application of vermicompost @ 4 t/ha significantly improved $\mathrm{N}, \mathrm{P}$ and $\mathrm{K}$ content in seed and straw. The positive influence of vermicompost application on nutrient content in cowpea crop appears to be due to improved nutrient levels both in the root zone and plant system. The increased availability of these nutrients in the root zone coupled with increased metabolic activity at cellular levels might have increased nutrient uptake and their accumulation in the vegetative plants. An improved metabolism to greater translocation of these nutrient to reproductive organs of the crop and ultimately increased the content in seed and straw. These results are in close conformity with those of Rajkhowa et al., (2000). Significant increase in $\mathrm{N}, \mathrm{P}$ and $\mathrm{K}$ uptake (Table 2) due to application of vermicompost @ 4 t/ha recorded under investigation.

Increased uptake of $\mathrm{N}, \mathrm{P}$ and $\mathrm{K}$ seems to be due to the fact that uptake of nutrient is product of biomass and its nutrient content. Thus, positive impact of vermicompost application on both these aspects ultimately led to higher accumulation of nutrient. These results are in line with the findings of Mathur (2000) and Rajkhowa et al., (2000).

\section{Effect of biofertilizers}

It is obvious from the data in (Table 2) that due to inoculation of cowpea seed with Rhizobium, PSB and Rhizobium + PSB there was a significant increase in nitrogen content and uptake in seed and straw of cowpea in comparison to no inoculation. The increase in nitrogen content in seed and straw with
Rhizobium + PSB was also statistically significant over Rhizobium as well as PSB inoculations. However, the increase in nitrogen content and uptake in seed and straw with inoculation of Rhizobium was statistically at par with that of PSB. The increase in nitrogen content and uptake in seeds of cowpea with Rhizobium, PSB and Rhizobium + PSB inoculations was to the extent of 10.14, 8.69, 13.33, 27.61, 23.54 and 47.27 per cent whereas, increase in the nitrogen content and uptake in straw was to the extent of $14.49,14.08,22.53,33.34,29.62$ and 56.76 per cent respectively, over no inoculation. An examination of data in table 2 revealed that due to inoculation of cowpea seeds with Rhizobium, PSB and Rhizobium + $\mathrm{PSB}$, there was a significant increase in phosphorus content and uptake in seed and straw of cowpea as compared to no inoculation.

The increase in phosphorus content and uptake in seed and straw with Rhizobium + PSB was also statistically significant over Rhizobium as well as PSB inoculations. However, the increase in phosphorus content and uptake in seed and straw with inoculation of Rhizobium was also statistically at par with that of PSB with the inoculation of cowpea seed by Rhizobium, PSB and Rhizobium + PSB. The increase in phosphorus content and uptake in seed was to the extent of $6.00,8.10$, $13.81,22.25,22.81$ and 47.60 per cent whereas, the increase in phosphorus content and uptake in straw was to the extent of $13.81,18.78,27.62,31.37,34.60$ and 62.75 per cent respectively, over no inoculation. A perusal of data in table 2 also indicate that due to inoculation of cowpea seed with Rhizobium, PSB and Rhizobium + PSB, there was a significant increase in potassium content and uptake in seed and straw of cowpea in comparison to on inoculation. The increase in potassium content and uptake in seed and straw with Rhizobium + PSB was also statistically significant over Rhizobium 
as well as PSB inoculations. However, the potassium content and uptake in seed and straw with inoculation of Rhizobium was statistically at par with that of PSB. The increase in potassium uptake in seed and straw of cowpea with Rhizobium, PSB and Rhizobium + PSB inoculations was to the extent of $34.12,28.34$ and 68.87 per cent whereas, increase in the potassium content in straw was to the extent of 29.17, 22.84 and 55.11 per cent respectively, over no inoculation. Significant increase in nitrogen phosphorus and potassium content of seed and straw and their total uptake by the crop was also observed with PSB inoculation (Table 2). PSB enhanced the availability of phosphorus to plants, which might have utilized by the crop in greater root development and nodulation that in turn resulted in higher nitrogen fixation in the soil by nodules. Thus, increased availability of nitrogen and phosphorus might have resulted in greater uptake by plant for proper development and ultimately increased their content and uptake in seed and straw. These results are in line with the findings of Yadav (2001) and Vasanthi and Subramanian, 2004 in blackgram also reported similar results. On the basis of one year experimentation, it may be concluded that the Application of vermicompost @ 6 t/ha and inoculation of Rhizobium + PSB improved nutrient content and uptake in seed and straw.

\section{References}

Anonymous. 2009. Rajasthan Agriculture Statistics at a Glance. Commissionerate of Agriculture, Rajasthan, Jaipur.p. 106.
Anonymous. 2011. Rajasthan Agriculture Statistics at a Glance, Commissionerate of Agriculture, Rajasthan, Jaipur. pp. 126-134.

Anonymous. 2012. Agricultural Production and Programmers. State Indian Agriculture, India. p. 83.

Kumawat, A., Pareek, B.L. and Yadav, R.S. 2010. Response of green gram (Vigna radiata) to biofertilizers under different fertility levels. Indian J. Agri. Sci., 80: 655-657.

Mathur, K. 2000. Effect of Rhizobium inoculation and various sources of nitrogen on growth and yield of summer greengram [Vigna radiata (L.) Willezek]. M.Sc. (Ag.) Thesis, Choudhary Charan Singh Agricultural University, Hisar. (Haryana)

Rajkhowa, D.S., Gogoi, A.K., Kandali, R. and Rajkhawa, K.M. 2000. Effect of vermicompost on mungbean nutrition. $J$. Indian Soc. Soil Sci., 48: 207-208.

Sharma, S.R. 2001. Effect of organic manure nutrients on symbiotic efficiency in cowpea. Indian J. Pulses Res., 15: 156-160.

Singh, B. and Nair, T.V.R. 1995. Effect of nitrogen fertilization on nodulation and nitrogen assimilation in cowpea. Crop Improvement, 22: 133-138.

Vaisya, V.K., Gayendregdkar, G.R. and Penday, R.L. 1983. Effect of Rhizobium inoculation on nodulation and grain yield of mungbean. Indian J. Microbiol., 23: 228-230.

Vasanthi, D. and Subramanian, S. 2004. Effect of vermicompost on nutrient uptake and protein content in blackgram. Legume Res., 27: 293295.

Yadav, B.L. and Jakhar, S.R. 2001. Effect of tillage and phosphorus fertilization on yield and water expense efficiency of rainfed mungbean. J. Indian Soc. Soil Sci., 49: 193194.

\section{How to cite this article:}

Khan V. M., Atik Ahamad, Yadav B. L. and Mohammad Irfan. 2017. Effect of vermicompost and biofertilizers on yield attributes and nutrient content and it's their uptake of cowpea [Vigna unguiculata (L.)Walp.]. Int.J.Curr.Microbiol.App.Sci. 6(6): 1045-1050.

doi: https://doi.org/10.20546/ijcmas.2017.606.120 